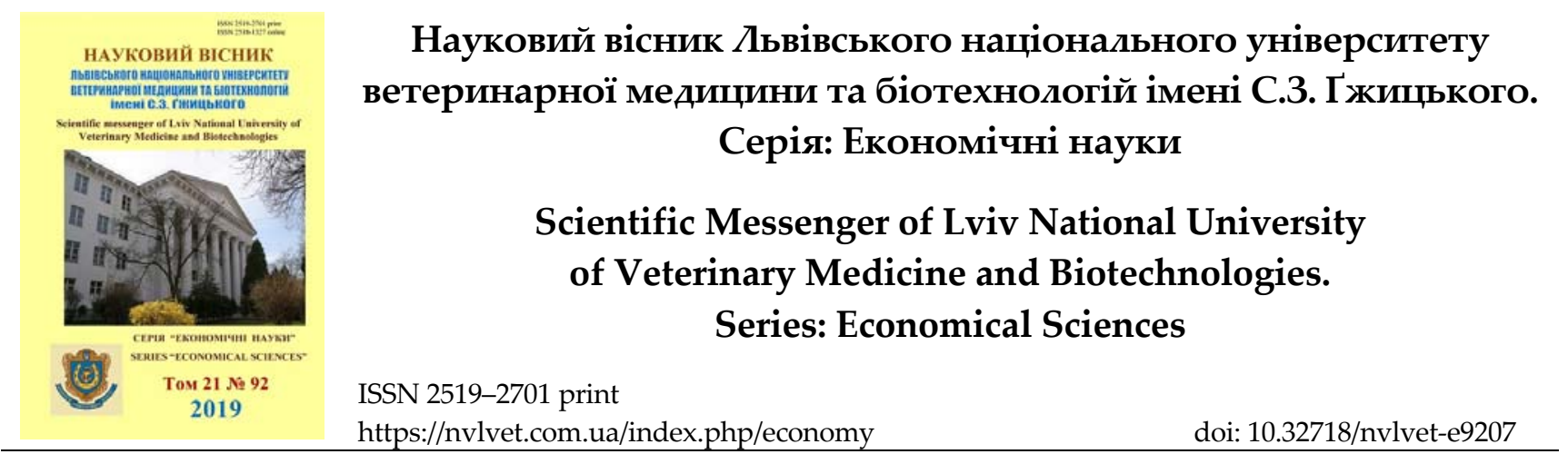

UDC 338.439

\title{
Cooperative activity of Ivan Porytko from rogatin
}

\author{
M. Shulskyi
}

Stepan Gzhytskyi National University of Veterinary Medicine and Biotechnologies Lviv, Ukraine

Article info

Received 21.01.2019

Received in revised form 22.02.2019

Accepted 25.02.2019

Stepan Gzhytskyi National University of Veterinary Medicine and Biotechnologies Lviv, Pekarska Str., 50, Lviv, 79010, Ukraine.

Tel.: +38-097-569-77-12 E-mail:Pretty_62@ukr.net

Shulskyi, M. (2019). Cooperative activity of Ivan Porytko from rogatin. Scientific Messenger of Lviv National University of Veterinary Medicine and Biotechnologies. Series: Economical Sciences, 21(92), 43-48. doi: 10.32718/nvlvet-e9207

The article highlighted the thick layer of activity of those co-operators, which ensure the implementation of theoretical developments of cooperation in the practical actions of business entities. At one of the numerous group of cooperative figures, namely: on the cooperative activity of Ivan Porytka attention was paid to the research process on the chosen topic of publication. In this article, the presentation of the research results is conducted in a certain logical sequence. The introduction substantiates the relevance of the chosen theme, its importance for further development of the cooperative movement in various spheres of social relations. Particular attention is paid to the activities of those cooperators who introduced theoretical developments into the practice of business entities. Each person in one or another kind of activity is characterized by a whole complex of both general and personal attributes that are inherent to it. These are, first of all, periods of birth, education and first steps of activities. Specific features of their implementation in the life of I. Porytka are reflected in table 1. Further activity of the person under study, which began at the beginning of the 20th century on the cooperative field, is reflected in the materials of table 2 and partly in table 3 . Here, in the specified forms, all of what I. Porytko practically practiced during the interwar period is represented. His activities were multifaceted and fruitful, which materialized in the creation of cooperatives. He acted not in himself, but in constant cooperation with his associates, representatives of the clergy, and others like that. All this in the complex provided success in the development of cooperation. tives.

Key words: Ivan Porytko, cooperation, cooperative movement, "Rural host", formation of coopera-

\section{Кооперативна діяльність вихідця з рогатинщини Івана Поритка}

\author{
М.Г. Шульський
}

Львівський національний університет ветеринарної медицини та біотехнологій імені С.3. Гжицького, м. Львів, Украӥна

Піднято товстий шар діяльності тих кооператорів, які забезпечують впровадження теоретичних напрацювань з кооперації у практичні дії суб 'єктів господарювання. На одного із чисельної групи кооперативних діячів, а саме: на кооперативну діяльність Івана Поритка звернуто увагу у прочесах дослідження за обраною темою публікації. В даній прачі виклад результатів дослідження проведено у певній логічній послідовності. У вступі обтрунтовано актуальність обраної теми, ї̈ важливість для подальшого розвитку кооперативного руху в різних сферах суспільних відносин. Особливу увагу при иьому сконцентровано на діяльність тих кооператорів, які впроваджували теоретичні розробки у практику діяльності господарюючих суб'єктів. Кожна особистість в тому чи тому видах діяльності характеризується цілим комплексом як загальних, так і особистих ознак, які притаманні їи. Це насамперед, пов'язано з народженням, навчання, першими кроками діяльності. Специфічні особливості їх здійснення у житті I. Поритка відображені в табличі 1. Подальша діяльність досліджуваної нами особистості, яка почалася на початку 20-х років ХХ століття на кооперативній ниві, відображена у матеріалах табличі 2 i частково в табличі 3. Тут у конкретизованих формах показано все те, чим практично займався I. Поритко у міжвоєнний період. Його діяльність була багатогранною і плідною, яка матеріалізовувалася у створенні кооперативів. Він діяв не сам, а в стійкій співпрачі зі свойми однодумиями, представниками духовенства тощо. Все це в комплексі забезпечувало успіх у розвитку кооперації. 
Ключові слова: Іван Поритко, коопераиія, кооперування, кооперативний рух, “Сільський господар”, формування кооперативів.

\section{Встуі}

Просторова цитата, що наведена у епіграфі даної публікації, найбільш повно передає усі складності розвитку української кооперації в умовах окупаційних режимів, з одного боку, та вказує на ті зусилля, завдяки яким розвивався кооперативний рух, з іншого (Vytanovych, 1964). Серед тих особистостей, які закладали практичні основи кооперації в тих складноважких обставинах життя українського суспільства, виділяється постать “студента Львівської торговельної школи Івана Поритка, велика заслуга” якого полягає в організації кооперативного руху на Рогатинщині. Саме в цих аспектах полягає суть поставленої проблеми, їі актуальність та важливість розвитку кооперації у різних сферах суспільних відносин.

\section{Матеріал і методи досліджень}

В основу проведення дослідження нами використано матеріали вивчення діяльності I. Поритка, які подані його дослідником Р. Коритком і поміщені у виданні Львівської комерційної академії (Ukrainski kooperatory, 1999). Обробку текстової Кориткової інформації проведено з використанням діалогового методу дослідження. Його суть полягає в тому, що ми формуємо питання щодо I. Поритка та його діяльності, а відповіді відшукуємо в тексті дослідника. Такі підходи до дослідження, на наше переконання, дають можливість поєднати сучасне (сформовані нами питання) і минуле (відповіді з вказаного тексту) в одній таблиці. Таким чином, те, що нас цікавить 3 діяльності І. Поритка, відображається у сформованих нами питаннях, відповіді на яких подаються з інформації про нього, яка є в публікації дослідника.

\section{Результати та їх обговорення}

Із наведеної текстової інформації цілком закономірно постає питання: то ким же був Іван Поритко? Спочатку відповімо в загальних формах, а з часом конкретизуємо їх деталізацію у складових кооперативного руху, в якому він брав активну і безпосередню участь. Отож, коли проаналізувати розвиток української кооперації з позицій історичної ретроспективи, то вартовиділити дві складові їі розвитку, в яких були зайняті українські кооператори. По-перше, можна виділити відомих кооператорів, які теоретично обгрунтували i практично довели об'єктивність та необхідність розвитку кооперативних процесів у різних сферах суспільних відносин. Сюди можна віднести таких діячів кооперативного руху, як: M.I. Туган-Барановський, I. Витанович, Ф. Щербина, К. Воблий, О. Луцький, Ю. Павликовський, Є. Храпливий та інші. Це, так би мовити, є зірки першої величини вітчизняної кооперації. Вони залишили нащадкам значний творчий спадок розвитку українського кооперування, який є основою для дослідження розвитку кооперативного руху в минулому, щоб обгрунтувати його функціонування на майбутнє. Їхні імена широко відомі як в Україні, так і за іii межами (Shulskyi \& Korobka, 2015).

По-друге, є ще інша чисельніша і одночасно менш відома група українських кооператорів, які своєю титанічною працею реалізовували теоретичнокооперативні напрацювання минулих поколінь шляхом створення і забезпечення діяльності певних кооперативних товариств. Ці зірки $є$ менш яскраві на кооперативному небосхилі, але більш потужнішоплодючі у практичній кооперативній діяльності. І ось про одного із тих зіркових практичних діячів створення кооперативних структур, а саме: про I. Поритка i йдеться в даній публікації. Насамперед наведемо коротко його біографічні дані (табл. 1).

Отож, з матеріалів, які подано в таблиці 1, бачимо що I. Поритко народився у кінці XIX століття (15 вересня 1895 р.) в с. Княгиничі, що на Рогатинщині. Досить нагадати, що м. Рогатин відоме із 1415 р. (Ukrainskyi radianskyi entsyklopedychnyi slovnyk, 1968). 3 цього повіту Галичини вийшла ціла плеяда відомих кооператорів, серед яких: I. Витанович (1899-1973), С. Кузик (1888-1947), В. Скробач (1921-2005) та інші. О.С. Городецький (1863-1928), хоча народився в Станіславському повіті, проте був одним із головних організаторів кооперативного руху на Рогатинщині. I. Поритко спочатку проходив свої життєві віхи традиційними шляхами, які притаманні кожній людині: навчання та формування світогляду. Однак покоління, до якого він належав, проходило період змужніння дещо по-іншому, ніж його попередники. I це не залежало від нього одного, а від тих глобальнограндіозних подій, що почали відбуватися на початку XX століття у світовому просторі. Вперше за період існування людства почалася Перша світова війна у 1914 p. I ця подія не могла не вплинути на подальші кроки вісімнадцятирічного юнака, який після закінчення гімназії не продовжував навчання, а діаметрально змінив вектор свого життєвого руху та добровільно зголосився до Січових Стрільців - української військової формації. І. Поритка зачислили до славної сотні Осипа Будзиковського.

3 цього приводу дещо уточнимо. В енциклопедичних виданнях, що вийшли з друку в умовах незалежної України, про Січових Стрільців зазначено: 1. "Українські C C" - військові підрозділи у складі АвстроУгорської армії, що були створені 1914 р. під час Першої світової війни. Існували до розпаду Австро Угорщини 1918. 2. Військові формування Центральної Ради і Директорії, створені 1917” (Tuhan-Baranovskyi, 2007). I весь цей тернистий шлях Українського Стрілецтва пройшов I. Поритко, дослужившись “до старшинських чинів - підхорунжого, четаря і поручика”. Відповіді на 4-6 питання таблиці 1 відображають весь цей напрям руху різними шляхами I. Поритка. 


\section{Таблиця 1}

Народження, навчання і перші кроки діяльності I. Поритка (Ukrainski kooperatory, 1999)

\begin{tabular}{|c|c|c|}
\hline $\begin{array}{l}\text { № } \\
\text { N/ח }\end{array}$ & Питання, сформовані нами & Відповіді із тексту вищевказаного джерела \\
\hline 1 & $\begin{array}{l}\text { Де народився І. Поритко і де } \\
\text { починав та продовжував навча- } \\
\text { тися? }\end{array}$ & $\begin{array}{l}\text { Народився він } 15 \text { вересня } 1895 \text { р. у селі Княгиничі Рогатинського повіту на } \\
\text { Станіславщині. Спочатку навчався у чотирикласній сільській школі, а потім } \\
\text { вступив до Рогатинської гімназії }\end{array}$ \\
\hline 2 & $\begin{array}{l}\text { Що являла Рогатинська академія } \\
\text { на цей час ? }\end{array}$ & $\begin{array}{l}\text { Була головним храмом виховання високосвідомих українських патріотів. У iï } \\
\text { стінах формувався його світогляд }\end{array}$ \\
\hline 3 & $\begin{array}{l}\text { До якої організації належав I. } \\
\text { Поритко і як вона вплинула на } \\
\text { його переконання? }\end{array}$ & $\begin{array}{l}\text { Належність до мілітарно-патріотичної організації “Молода Січ”, що діяла в } \\
\text { гімназії, сформувала у І. Поритка переконання, що утвердження власної держа- } \\
\text { вності може відбутися лише шляхом збройної боротьби }\end{array}$ \\
\hline 4 & $\begin{array}{l}\text { Які дії здійснив I. Поритко у } \\
\text { зв'язку з початком Першої сві- } \\
\text { тової війни? }\end{array}$ & $\begin{array}{l}\text { Тому вісімнадцятирічним юнаком у } 1914 \text { р. він добровільно зголосився до } \\
\text { Січових Стрільців - української військової формації, яка виникла на початку } \\
\text { війни. І. Поритка зачислили до славної сотні Осипа Будзиковського, в якій } \\
\text { немало було гімназистів з Рогатина }\end{array}$ \\
\hline 5 & $\begin{array}{l}\text { Яким видом діяльності займався } \\
\text { І. Поритко в період Першої } \\
\text { світової війни і до чого дослу- } \\
\text { жився? }\end{array}$ & $\begin{array}{l}\text { У 1916-1918 рр. став вишкільним інструктором і навчав військової справи } \\
\text { молоде поповнення українського війська. Дослужився до старшинських чинів - } \\
\text { підхорунжого, четаря і поручика }\end{array}$ \\
\hline 6 & $\begin{array}{l}\text { Як сприйняв І. Поритко прого- } \\
\text { лошення ЗУНР (Західноукраїн- } \\
\text { ської народної республіки)? } \\
\end{array}$ & $\begin{array}{l}3 \text { моменту проголошення ЗУНР вступив до лав УГА і воював за звільнення } \\
\text { Львова. Побував і на сході України. Після поразки національно-визвольних } \\
\text { змагань потрапив до польського полону }\end{array}$ \\
\hline 7 & $\begin{array}{l}\text { Що робив І. Поритко після зві- } \\
\text { льнення з полону? }\end{array}$ & $\begin{array}{l}\text { Звільнившись } 3 \text { табору військовополонених, І. Поритко вступив на курси Ви- } \\
\text { щої торгівельно-експортової школи у Відні. Коли у Львові відкрилася школа } \\
\text { такого ж типу, перевівся до неї, де й закінчив своє навчання }\end{array}$ \\
\hline 8 & $\begin{array}{l}\text { Які обставини сприяли йому, } \\
\text { щоб відвідувати рідний край i } \\
\text { займатися кооперацією? }\end{array}$ & $\begin{array}{l}\text { Близькість Львова і Рогатина давала змогу студентові І. Пориткові часто відві- } \\
\text { дувати рідний край, жити його життям і проблемами. Незважаючи на те, що } \\
\text { був студентом, активно включився до організації повітового Союзу кооператив } \\
\text { (ПСК - примітка М.Ш). І відразу потрапив в око поліції }\end{array}$ \\
\hline 9 & $\begin{array}{l}\text { Що було підозрою поліції до I. } \\
\text { Поритка ? }\end{array}$ & $\begin{array}{l}\text { Причиною було те, що І. Поритко вступив до повітової студентської секції при } \\
\text { товаристві “Просвіта”. Якоюсь мірою це слугувало ширмою, бо йому доводи- } \\
\text { лося виконувати завдання Української військової організації, куди вступив за } \\
\text { рекомендацією сотника УГА Дмитра Паліїва, що знав І. Поритка з часів визво- } \\
\text { льних змагань }\end{array}$ \\
\hline
\end{tabular}

Історія показує, що всі війни, початі різними країнами проти різних країн, тривають різні періоди (семилітні, навіть столітні), однак завжди закінчуються. I Перша світова, а згодом війна за незалежність України закінчились. Перша привела до розпаду імперій і на їх тлі утворення незалежних національних держав, друга - до втрати незалежності Української держави. У ході завершальних цих дій I. Поритко потрапив у польський полон, після звільнення з якого почав надолужувати те, що було упущено в зв'язку з початком Першої світової війни - подальшим навчанням у торговельно-експортових школах Відня і Львова та початком його кооперативної діяльності. Відповіді на 7 9 питання таблиці 1 відображають ці процеси детально і послідовно. Саме через ці обставини ми не будемо детально аналізувати цей період навчання та діяльності I. Поритка, а перейдемо до наступних етапів його участі в процесах щодо створення кооперативів i забезпечення їх функціонування. Ця інформація подана у таблиці 2 і частково у таблиці 3.

Отож, дещо прокоментуємо матеріали, що наведені в таблиці 2. У міжвоєнний період початковим і визначальним роком діяльності I. Поритка став 1923 р. Саме у цей рік рогатинці проявили ентузіазм у намаганні “започаткувати створення кооперативів у повіті”. У налагодженні цих процесів брали участь багато професійних кооператорів.

Іван Поритко, Петро Бігус, Дмитро Хоптяк, Дмитро Вирста, Василь Воробець і священик о. Степан Городецький на офіційному рівні заснували повітовий союз кооперативів. При цьому, важливо зазначити, що Головою надзірної ради було обрано священика о. С. Городецького, начальним директором - С. Кузика, а його заступником - I. Поритка.

Серед названих вище осіб привертає увагу постать о. С. Городецького, якого було обрано Головою надзірної ради. Суть неоднозначності і разом з тим оригінальності обрання особи духовного сану на керівну кооперативну посаду викликає багато запитань 3 цього приводу в умовах сьогодення. Насамперед, як це сталося, що священик не тільки бере участь у створенні кооперативних структур, а й очолює їх? 3 погляду минулого це не було випадковим явищем, а цілком закономірними процесами - участь духовенства не тільки у розвитку кооперації, а і в інших сферах суспільних відносин. Це, до речі, може бути незрозумілим і в деякій мірі дивним як для населення і духовенства, скажімо, Російської імперії чи окремих країн Західної Свропи, однак не для Галичини. Саме галицьке духовенство брало активну участь у господарській діяльності галицького краю. I не тільки у цій сфері, а і в інших складових суспільства. 


\section{Таблищя 2}

Подальша діяльність I. Поритка на кооперативній ниві (Ukrainski kooperatory, 1999)

\begin{tabular}{|c|c|c|}
\hline $\begin{array}{l}\text { № } \\
\text { П/ח }\end{array}$ & Питання, сформовані нами & Відповіді з тексту вищевказаного джерела \\
\hline 1 & $\begin{array}{l}\text { Яку роль відіграв } 1923 \text { р. в діяль- } \\
\text { ності кооператорів на Рогатин- } \\
\text { щині? }\end{array}$ & $\begin{array}{l}1923 \text { р. став визначальним у намаганнях рогатинських ентузіастів започаткува- } \\
\text { ти створення кооперативів у повіті. Однодумці - Степан Кузик, Іван Поритко, } \\
\text { Петро Бігус, Дмитро Хоптяк, Дмитро Вирста, Василь Воробець і священик } \\
\text { о. Степан Городецький - офіційно заснували повітовий Союз кооператив }\end{array}$ \\
\hline 2 & $\begin{array}{l}\text { Хто із засновників кооперативу } \\
\text { увійшов у його керівний склад? }\end{array}$ & $\begin{array}{l}\text { Головою надзірної ради обрали священика о. С. Городецького, начальним } \\
\text { директором ПСК - С. Кузика, а його заступником - I. Поритка }\end{array}$ \\
\hline 3 & $\begin{array}{l}\text { Які були перші кроки діяльності } \\
\text { ПСК і як здійснювалась його } \\
\text { діяльність? }\end{array}$ & $\begin{array}{l}\text { Перші кроки діяльності ПСК були тяжкі. Постійно відчувався брак грошей і } \\
\text { фахівців торговельної справи. Перші товари члени дирекції возили із Львова у } \\
\text { наплічниках, а потім - возами }\end{array}$ \\
\hline 4 & $\begin{array}{l}\text { Якими показниками характеризу- } \\
\text { валася діяльність ПСК? }\end{array}$ & $\begin{array}{l}\text { Якщо у } 1923 \text { р. у повіті налічувалося лише } 23 \text { кооперативів, то вже у } 1927 \text { р. їх } \\
\text { мережа охопила всі села. У Рогатині, в центрі міста, виріс триповерховий дім } 3 \\
\text { власним магазином, було також здано в експлуатацію басейн для вапнування } \\
\text { яєць, що десятьма вагонами експортувалися за кордон }\end{array}$ \\
\hline 5 & $\begin{array}{l}\text { Які зміни відбулися в діяльності } \\
\text { ПСК згодом? }\end{array}$ & $\begin{array}{l}\text { У } 1930 \text { р. ПСК змінив назву на ОСК - Окружний союз кооператив у Рогатині, } \\
\text { бо до нього приєдналися повітові союзи Галича, Перемишлян і Ходорова. } 3 \\
\text { початку } 1936 \text { р., коли С. Кузик переїхав до Львова, ОПСК очолив його заступ- } \\
\text { ник і перший помічник І. Поритко }\end{array}$ \\
\hline 6 & $\begin{array}{l}\text { В чому були заслуги I. Поритка } \\
\text { на посаді начального директора } \\
\text { ОПСК? }\end{array}$ & $\begin{array}{l}\text { Однією із заслуг І. Поритка як начального директора ОПСК була його смілива } \\
\text { ініціатива купувати у селян свиней і відправляти їх до м’ясних комбінатів } \\
\text { Львова, Катовиць, Шльонська і частково до Німеччини }\end{array}$ \\
\hline 7 & $\begin{array}{l}\text { Як раніше селяни продавали } \\
\text { свиней і за яких відносин? }\end{array}$ & $\begin{array}{l}\text { Раніше свиней у селян купували всякі шахраї, які безсоромно обдурювали їх. } \\
\text { Рішення ОПСК вибити з рук пройдисвітів добрий заробіток викликало з їхньо- } \\
\text { го боку шалений опір. Спочатку вони обезчестили ОПСК, почали вдаватись до } \\
\text { різноманітних провокацій, нападали на будинок ОПСК, трощили там меблі... } \\
\text { власними силами дав відсіч конкурентам }\end{array}$ \\
\hline 8 & $\begin{array}{l}\text { Як здійснював ОПСК цінову полі- } \\
\text { тику? }\end{array}$ & $\begin{array}{l}\text { Продукцію, яку купував у населення, оцінював вище, ніж вона коштувала на } \\
\text { міських ринках Рогатина, Галича, Перемишля і Ходорова. Така ціна, точна } \\
\text { вага, чемне обслуговування робили добру справу - селяни горнулися до спів- } \\
\text { праці з ОПСК }\end{array}$ \\
\hline
\end{tabular}

Наведемо лише один приклад. Саме священик М. Вербицький (1815-1870) написав музику до гімну української держави. Де, в який час, в якій країні священик виконав таку грандіозну місію? Відповідь дамо ми - це відбулося в Галичині, що входила до складу Австро-Угорської монархії, у середині XIX століття. Одночасно зауважимо, що автор цієї публікації підготовив комплекс наукових статей про участь галицького духовенства не тільки у сферах розвитку кооперативного руху, а і в інших складових суспільних відносин. Однак, на превеликий жаль, у цьому енциклопедичному видані не сказано, що М. Вербицький був греко-католицьким священиком (Slipushko, 2008). Незрозуміло, неприємно, але факт. У матеріалах наведеної таблиці привертають увагу 2 і 3-тє питання та відповіді на них. Отож, тут відображено у спресованих формах весь цей складний шлях формування кооперативів. Можна тільки собі уявити, яких титанічних зусиль докладали члени дирекції для забезпечення діяльності кооперативів на початкових стадіях їх формування, доставляючи перші товари у наплічниках зі Львова, а згодом - возами. I цей ентузіазм та зусилля для його реалізації забезпечили успіх у кооперативній діяльності. Уже у 1927 р. мережа кооперативів охопила всі села Рогатинського повіту, почалось будівництво приміщень, “здано в експлуа- тацію басейн для вапнування яєць, що десятьма вагонами експортувались за кордон”. Навіть за сьогоднішніми вимірами ці результати вражають своїми матеріалізованими величинами.

Після здійснення цих стартових кроків відбувались наступні не менш потужні, а саме: розширення географії діяльності шляхом приєднання подібних кооперативів Галича, Перемишлян, Ходорова та охоплення інших сфер діяльності, зокрема закупівлі у населення відгодованих свиней і відправлення їх до “м'ясних комбінатів Львова, Катовиць, Шльонська і частково до Німеччини". Крім того, успіх кооперативної діяльності у значній мірі забезпечувала ефективна цінова політика. Центральною фігурою цих успіхів був I. Поритко, обіймаючи посади начального директора ОПСК, оскільки попередній директор С. Кузик переїхав до Львова. Патріотично-господарська діяльність на кооперативній ниві забезпечила йому зростання авторитету і пошану серед населення повітів. Підставою для таких тверджень є обрання I. Поритка головою філії “Сільський господар”, членом надзірних комісій тощо. Крім того, варто зауважити, що зміцнення повітової кооперації, безумовно, сприяло збільшення прибутків, значну частину яких було використано на благочинні цілі. Все це в комплексі відображено у відповідях на 1-2-ге питання таблиці 3. 
Таблиця 3

Оцінка діяльності I. Поритка і останні роки життя (Ukrainski kooperatory, 1999)

\begin{tabular}{|c|c|c|}
\hline $\begin{array}{l}\text { № } \\
\Pi / \Pi \\
\end{array}$ & Питання, сформовані нами & Відповіді із вище зазначеного джерела \\
\hline 1 & $\begin{array}{l}\text { Яку пошану мав І. Поритко, } \\
\text { перебуваючи на посаді ОПСК і } \\
\text { голови філії “Сільський госпо- } \\
\text { дар”, в яких структурах він } \\
\text { брав участь? }\end{array}$ & $\begin{array}{l}\text { I. Поритко як директор ОПСК і патріот здобув велику пошану та авторитет } \\
\text { серед населення повітів і українських громадських організацій. Його обирали } \\
\text { головою філії “Сільського господаря”, членом декількох надзірних рад і комісій } \\
\text { кооперативних центрів у Львові, до складу дирекції Украінбанку }\end{array}$ \\
\hline 2 & $\begin{array}{l}\text { Як під його керівництвом роз- } \\
\text { вивалась повітова кооперація і } \\
\text { як він використовував одержані } \\
\text { прибутки? }\end{array}$ & $\begin{array}{l}\text { Під його орудою міцніла повітова кооперація, зростав експорт сільськогоспо- } \\
\text { дарських продуктів, зокрема у Німеччину і Чехо-Словаччину. Маючи у своєму } \\
\text { розпорядженні великі фонди, ОПСК надавав щедру допомогу рогатинській } \\
\text { гімназії, сільським школам, товариству “Просвіта"; допомагав у селах будувати } \\
\text { читальні }\end{array}$ \\
\hline 3 & $\begin{array}{l}\text { Які зміни відбулися у вересні } \\
1939 \text { р. ? }\end{array}$ & $\begin{array}{l}\text { У вересні } 1939 \text { р., коли у Рогатин мало вступити радянське військо, повітовий } \\
\text { староста перед своєю втечею призначив так звану тимчасову управу з п’яти осіб, } \\
\text { покликану стежити за порядком у повіті. Головою управи був обраний І. Поритко }\end{array}$ \\
\hline 4 & $\begin{array}{l}\text { Які функції виконував } \\
\text { I. Поритко у 1941-1944 рр. ? }\end{array}$ & $\begin{array}{l}\text { У } 1941-1944 \text { pр. І. Поритко був директором Української торговельної акційної } \\
\text { спілки у Кракові та Львові. У } 1944 \text { р. вимушено опинився в еміграції. Після } \\
\text { тривалих митарств замешкав у США, у Філадельфії }\end{array}$ \\
\hline 5 & $\begin{array}{l}\text { Яку діяльність він здійснював у } \\
\text { Філадельфії (США)? }\end{array}$ & $\begin{array}{l}\text { У } 1951 \text { р. його обрали членом Контрольної комісії суспільної служби злученого } \\
\text { українсько-американського допомогового комітету, в } 1952 \text { р. - до управи коор- } \\
\text { динаційної комісії, а в } 1969 \text { р. - членом Дирекційної ради... у фінансовій інсти- } \\
\text { туції “Українська щадниця”, був ії директором }\end{array}$ \\
\hline 6 & $\begin{array}{l}\text { Ще в яких видах діяльності } \\
\text { брав участь І. Поритко? }\end{array}$ & $\begin{array}{l}\text { Був одним із ініціаторів створення на теренах США та Канади товариства “Рога- } \\
\text { тинщина" і видання історико-краєзнавчого збірника "Рогатинська земля”... } \\
\text { часто дописував до часопису “Свобода”, друкував на його сторінках спогади про } \\
\text { національно-визвольну війну } 1914-1920 \text { рр. }\end{array}$ \\
\hline 7 & $\begin{array}{l}\text { Яку вартість мають його статті } \\
\text { і коли помер I. Поритко? }\end{array}$ & $\begin{array}{l}\text { Велику вартість мають статті про Листопадовий чин у Львові і про бої, які вели- } \\
\text { ся } 3 \text { поляками за визволення міста. Автор був безпосереднім учасником цих } \\
\text { подій. Помер І. Поритко } 1980 \text { р. на } 85 \text { році життя і похований на українському } \\
\text { цвинтарі у Фак Чейсі в Пенсильванії }\end{array}$ \\
\hline
\end{tabular}

Подальша діяльність і доля I. Поритка відображена у відповідях на 3-7-ме питання раніше названої таблиці 3. Не будемо деталізовано коментувати все те, що випало зробити, пережити і здійснити йому на своєму досить складному і тернистому шляху. Все це деталізовано описав дослідник його діяльності Р. Коритко, а ми у діалоговій формі це подали у таблиці 3. Однак дещо згадаємо. 3 приходом радянських військ (1939 р.) на долю I. Поритка випала тяжка ноша проблем відходу старої влади і приходу нової, адже "повітовий староста перед своєю втечею призначив так звану тимчасову управу з п'яти осіб, покликану стежити за порядком у повіті. Головою управи був обраний I. Поритко”. У цих умовах бути керівником повіту $є$ найбільш складною, відповідальною і навіть ризикованою для життя діяльністю. У цих надто складних і маловизначених процесах необхідно було проявити гнучкість у розробці і прагматичність в практичній реалізації прийнятих рішень. Із цими проблемами I. Поритко успішно справився, що вказує на його високі організаторські здібності.

В період Другої світової війни та ії закінчення I. Поритко перебував в еміграції, працюючи в різних спілках, комісіях, товариствах. Одночасно він писав статті до часопису “Свобода" з концентрацією уваги на національно-визвольну війну 1914-1920рp. I це цілком закономірно, адже у цих діях і подіях він брав безпосередню участь.

\section{Висновки}

На закінчення цієї публікації відзначимо, що I. Поритко, його напрацювання на кооперативній ниві $\epsilon$ важливими підвалинами для розвитку кооперації в умовах формування ефективної національної економіки. Адже у сьогоднішніх умовах в Україні є достатньо фахівців, які обгрунтовують, як необхідно розвивати кооперацію, проте у нас мало таких спеціалістів, які на практиці реалізовують теоретичні напрацювання щодо розвитку кооперативного руху. I саме для усунення таких недоліків слід вивчати і використовувати досвід кооператорів-практиків, серед яких виділяється постать I. Поритка.

Перспективи подальших досліджень. Через вищеназвані обставини для сьогоднішніх і майбутніх умов формування кооперативних структур нам необхідно продовжувати досліджувати кооперативну діяльність таких кооператорів минулого, як I. Поритко, а його цінні напрацювання використовувати в процесах створення кооперативів як у сільському господарстві, так і в інших сферах суспільних відносин. Все це в комплексі вимагає подальших всебічних i науково обгрунтованих досліджень розвитку кооперативного руху як в Україні, так і в інших країнах світового простору. Все цінне варто використовувати в практичній діяльності сільськогосподарських формувань в системі АПК. 


\section{References}

Vytanovych, I. (1964). Istoriia ukrainskoho kooperatyvnoho rukhu. Niu-York (in Ukrainian).

Slipushko, O.M. (2008). Ukraina. Entsyklopedychnyi slovnyk. K.: Akonit (in Ukrainian).

Tuhan-Baranovskyi, M. (2007). Kooperatsiia, sotsialnoekonomichna pryroda yii ta meta. Ukrainska ekonomichna dumka: Khrestomatiia. Uporiad. S.M. Zlupko. K.: Znannia, 436-443 (in Ukrainian).

Ukrainski kooperatory (1999). Istorychni narysy. Knyha 1. Lviv (in Ukrainian).
Ukrainskyi radianskyi entsyklopedychnyi slovnyk (1968). $\mathrm{V}$ trokh tomakh, t. 3. K.: Holovna redaktsiia Ukrainskoi radianskoi entsyklopedii AN URSR (in Ukrainian).

Shulskyi, M.H., \& Korobka, S.V. (2015). TuhanBaranovskyi pro sotsialno-ekonomichnu pryrodu i metu kooperatsii. "Rol i znachennia naukovoi spadshchyny M.Tuhan-Baranovskoho u rozvytku suchasnoi ekonomichnoi nauky" [tekst] [31 berez-nia 2015]: zb. tez. Lviv, 143-156 (in Ukrainian). 